\title{
Parvovirus B19 antibodies and correlates of infection in pregnant women attending an antenatal clinic in central Nigeria
}

\author{
Samuel E Emiasegen ${ }^{1,2}$, Lohya Nimzing ${ }^{1}$, Moses P Adoga ${ }^{3}{ }^{+},{\text {Adamu Y Ohagenyi }{ }^{4} \text {, Rufai Lekan }}^{5}$ \\ 'Department of Medical Microbiology, Faculty of Medical Sciences, University of Jos, Plateau State, Nigeria \\ ${ }^{2}$ Laboratory Department, General Hospital Akwanga, Keffi, Nasarawa State, Nigeria ${ }^{3}$ Department of Biological Sciences, \\ Microbiology Unit, Nasarawa State University, Keffi, Nasarawa State, Nigeria ${ }^{4}$ Nasarawa State Hospitals Management Board, \\ Lafia, Nasarawa State, Nigeria ${ }^{5}$ National Blood Transfusion Center, Jos, Plateau State, Nigeria
}

Human parvovirus B19 infection is associated with spontaneous abortion, hydrops foetalis, intrauterine foetal death, erythema infectiosum (5th disease), aplastic crisis and acute symmetric polyarthropathy. However, data concerning Nigerian patients with B19 infection have not been published yet. The purpose of this study was to establish the prevalence of $B 19 \operatorname{Ig} G$ and $\operatorname{IgM}$ antibodies, including correlates of infection, among pregnant women attending an antenatal clinic in Nigeria. Subsequent to clearance from an ethical committee, blood samples were collected between August-November 2008 from 273 pregnant women between the ages of 15-40 years who have given their informed consent and completed self-administered questionnaires. Recombinant IgG and IgM enzyme linked immunosorbent assay kits (Demeditec Diagnostics, Germany) were used for the assays. Out of the 273 participants, 111 (40.7\%) had either IgG or IgM antibodies. Out of these, 75 (27.5\%) had IgG antibodies whereas 36 (13.2\%) had IgM antibodies, and those aged 36-40 years had the highest prevalence of $\operatorname{Ig} G$ antibodies. Significant determinants of infection $(p<0.05)$ included the receipt of a blood transfusion, occupation and the presence of a large number of children in the household. Our findings have important implications for transfusion and foeto-maternal health policy in Nigeria. Routine screening for B19 IgM antibodies and accompanying clinical management of positive cases should be made mandatory for all Nigerian blood donors and women of childbearing age.

Key words: parvovirus B19 - antibodies - incidence - prevalence - blood transfusion - risk factors

Parvovirus B19, also referred to as B19, is a small, non-enveloped, single-stranded DNA virus that belongs to the family Parvoviridae. This virus is the primary aetiologic agent of erythema infectiosum (5th disease) and aplastic crisis in patients with chronic haemolytic anaemia (Elnifro et al. 2009). The infection during pregnancy may account for thousands of incidences of foetal loss per annum in Europe, North America and beyond (Corcoran \& Doyle 2004). A common mode of transmission is through personal contact via aerosol or respiratory secretions. Iotrogenic transmission via contaminated blood products, such as clotting factor concentrates, also occurs (Elnifro et al. 2009).

Transplacental transmission of parvovirus B19 during pregnancy is one of the leading causes of nonimmune foetal hydrops, spontaneous abortion or intrauterine foetal death (Skjöldebrand-Sparre et al. 2000); it has been reported that intrauterine foetal death and miscarriage occur more during the second trimester (Johansson et al. 2008, Silingardi et al. 2009). Although B19 was initially discovered in 1974 (and the discovery

+Corresponding author: adogamoses@yahoo.com

Received 30 September 2010

Accepted 14 January 2011 published in 1975), it was not associated with disease until 1981, when it was linked to aplastic crisis, fifth disease, spontaneous abortion and acute arthritis (Cossart et al. 1975, Heegaard \& Brown 2002).

B19 may also stimulate a cellular process that initiates apoptosis (Morey et al. 1993), which might account for the minimal inflammatory response observed in infected tissues (Gratacós et al. 1995). B19 infection of megakaryocytes, placental cells, foetal liver cells and myocardial cells results in anaemia, which can lead to high-output congestive heart failure, causing foetal circulatory compromise. The risk of foetal demise is highest during the first trimester and is considered to be as high as $10 \%$ in women who are infected prior to the 20th week of gestation (Markenson \& Yancey 1998). The P blood group antigen, which serves as a receptor for B19, has been detected in villous trophoblast cells of placental tissues in varying amounts during the course of pregnancy; in the first trimester of pregnancy, the level of the $\mathrm{P}$ antigen is very high. This high level of globoside receptor in placental cells during early pregnancy may act as a pathway for B19 to be transmitted from mother to foetus whereby the virus can subsequently infect erythroid progenitor cells for replication (Heegaard \& Brown 2002, Silingardi et al. 2009).

There are limited data on the incidence, prevalence and correlates of B19 infection in Nigeria, a western country of Africa. However, a recent study conducted in Libya, another African country, reported $61 \% \operatorname{IgG}$ and $5 \% \operatorname{IgM}$ antibodies in pregnant women (Elnifro et 
al. 2009). Generally, the presence of IgG antibodies is indicative of past exposure to an antigen (prevalence), whereas IgM antibodies represent recent infection with an agent (Obeid \& Alzahrani 2010).

There are no published studies on the incidence of B19 infection in Nigeria despite the importance of such data in health policy formulation. Therefore, we initiated the first serosurvey to establish the frequency of the marker of recent cases, prevalence and correlates of infection among pregnant women attending Plateau Specialist Hospital in Jos, state of Plateau, located in north-central Nigeria.

\section{PATIENTS, MATERIALS AND METHODS}

Study area - The study area was Jos, a city located in the north-central geo-political zone of Nigeria. It is located at $9^{\circ} 56^{\prime} \mathrm{N} 8^{\circ} 53^{\prime} \mathrm{E}$, high on the Jos Plateau, at an altitude of 4,062 feet $(1,217 \mathrm{~m})$ above sea level. Jos has a more temperate climate than the rest of Nigeria, with an average monthly temperature range from $70^{\circ} \mathrm{F}-77^{\circ} \mathrm{F}$ or $21^{\circ} \mathrm{C}-25^{\circ} \mathrm{C}$. Jos has a population of $510,300,000$, making it the 10th largest city in Nigeria (Wikipedia 2010).

Study population - The study subjects included in this study were pregnant women who attended the antenatal clinic in Plateau State Specialist Hospital, Jos, between August-November 2008. The hospital had an average of 70 pregnant women attending the antenatal clinic weekly. Two hundred and seventy three subjects participated in this study. Questionnaires were self-administered by the participants and information on: (i) gestational age, (ii) history of complication, (iii) number of children in a household, (iv) history of blood transfusion and (v) occupation were obtained.

Ethical considerations - Clearance from the Health Research Ethics Committee of Plateau State Specialist Hospital was obtained in accordance with the Code of Ethics for Biomedical Research involving human subjects. Signed, informed consent was also obtained from each subject.

Inclusion and exclusion criteria - The study included women who were pregnant, attended the antenatal clinic and provided signed consent forms and self-administered questionnaires. The exclusion criteria were absence of pregnancy, an age below 15 or above 40 years and failure to sign a consent form.

Specimen collection - After collection of the signed consent forms and self-administered questionnaires, $5 \mathrm{~mL}$ of blood from each subject was aseptically collected by venepuncture of the cubital vein using disposable needles and syringes. The samples were collected between August-November 2008 and taken to the Nanel Medical Laboratory, Jos, where the sera were separated into sample vials and stored at $-20^{\circ} \mathrm{C}$ until assayed.

Technique for assaying $\operatorname{Ig} G$ and $\operatorname{IgM}$ antibodies and interpretation of the results - The Demeditec parvovirus B19 IgG and IgM enzyme immunoassay kits (Demeditec Diagnostics, Kiel-Wellsee, Germany) were used for the in vitro qualitative and semi-quantitative measurement of the amount of immunoglobulin class antibodies for
B19 present in the serum, according to the manufacturer's instructions. The microtiter wells were coated with recombinant parvovirus B19 antigen (VP1 proteins). The antigen was derived from the entire VP1 unique region of B19. The test kits were designed for the measurement of parvovirus infections in humans only.

Prevalence was defined by the presence of $\mathrm{B} 19 \mathrm{IgG}$ antibodies in the tested sera and subjects who demonstrated the presence of IgM antibodies were considered to be cases of recent infection with B19. Positive or negative cases were determined by comparing the absorbance value of each sample with that of the cut-off value. Based on the manufacturer's instructions, specimens with an absorbance value less than the cut-off value were recorded as negative; specimens with a value above the cut-off value were recorded as positive.

Statistical analysis - The Pearson Chi-square tests were calculated at a $95 \%$ confidence interval using the statistical software SPSS version 15.0 (SPSS Inc, Chicago, USA). $p$ values $\leq 0.05$ were considered significant.

\section{RESULTS}

A total of 273 pregnant women participated. Overall, 111 (40.7\%) participants had either IgG or IgM antibodies, 75 (27.5\%) participants had B19 IgG antibodies and 36 (13.2\%) participants had parvovirus B19 IgM antibodies.

Pregnant women aged 36-40 years had the highest prevalence of $\operatorname{IgG}$ antibodies of $37.5 \%$ (Table I). A history of blood transfusion (in the last 5 years) and occupation were both significant determinants of recent cases of B19 infection in this population (Table II); however, having more children in the household was a significant determinant of B19 prevalence (Table III) $(p<0.05)$. Tables II and III illustrate the correlates of parvovirus B19 infection.

\section{DISCUSSION}

There are limited data concerning human parvovirus B19 infection in Africa in spite of the implications of such a dearth of data on health policy formulation. In the first seroepidemiologic study of B19 infection in Ni-

TABLE I

Age distribution of parvovirus B19 antibodies among pregnant women in Nigeria

Sera analyzed

\begin{tabular}{lcccc}
\hline $\begin{array}{l}\text { Age } \\
\text { (years) }\end{array}$ & $\begin{array}{c}\text { Number } \\
\text { analyzed }\end{array}$ & $\begin{array}{c}\text { Positive sera } \\
\mathrm{n}(\%)\end{array}$ & $\begin{array}{c}\text { IgM presence } \\
\mathrm{n}(\%)\end{array}$ & $\begin{array}{c}\text { IgG presence } \\
\mathrm{n}(\%)\end{array}$ \\
\hline $15-20$ & 54 & $18(33.3)$ & $9(16.7)$ & $9(16.7)$ \\
$21-25$ & 78 & $33(42.3)$ & $12(15.4)$ & $21(26.9)$ \\
$26-30$ & 69 & $30(43.5)$ & $9(13)$ & $21(30.4)$ \\
$31-35$ & 48 & $21(43.8)$ & $6(12.5)$ & $15(31.3)$ \\
$36-40$ & 24 & $9(37.5)$ & $0(0)$ & $9(37.5)$ \\
\hline Total & 273 & $111(40.7)$ & $36(13.2)$ & $75(27.5)$ \\
\hline
\end{tabular}

IgM: $\mathrm{X}^{2}=4.57, \mathrm{p}=0.34 ; \mathrm{IgG}: \mathrm{X}^{2}=5.04, \mathrm{p}=0.28$. 
geria, we hereby report recent infection cases of $13.2 \%$, a prevalence of $27.5 \%$ and overall cases of either IgG or IgM antibodies of $40.7 \%$. Interestingly, our findings are consistent with reports in other parts of the world. For instance, a study conducted in Iran by Keikha et al. (2006) reported $10.3 \%$ IgM antibodies and $21.8 \%$ prevalence during pregnancy. In a review article, Kaur and Basu (2005) estimated that $30-60 \%$ of blood donors have $(\mathrm{IgG})$ antibodies to B19, which is indicative of immunity rather than chronic persistent infection.

In Africa, Schwarz et al. (1989) and Letaïef et al. (1997) reported a B19 prevalence of $58.4 \%$ and $65 \%$ in Malawi and Tunisia, respectively. More recently, Elnifro et al. (2009) reported a prevalence of $\operatorname{IgG}$ and IgM antibodies of $61 \%$ and $5 \%$, respectively, among pregnant women in Libya. This shows a relatively high rate of immunity $(61 \%)$ against a lower rate $(5 \%)$ of active transmission among their study population. The low prevalence of $27.5 \%$ from our study indicates that a lower proportion of immune individuals participated in our study population. However, consistent with our findings, Kishore et al. (2010) reported a low seroprevalence of $39.9 \%$ in a population of Indian blood donors, which led him to conclude that a large proportion of north Indians are susceptible to infection with B19. The $21.8 \%$ prevalence reported by Keikha et al. (2006) in a population of Iranian pregnant women also agrees with our findings.
The $13.2 \%$ rates of $\operatorname{IgM}$ antibodies recorded from our subjects is alarming because a high rate of IgM antibodies indicates the active transmission of this agent in the general population, especially to pregnant women, with its subsequent implications. We therefore, recommend a case-control study that will investigate the role that maternal B19 infection plays in abortion, intra-uterine foetal death and other complications among pregnant Nigerian women.

We discovered that the rate of IgG antibodies increased with age and that the rate of IgM antibodies decreased with age. Although it did not reach statistical significance, this observation agrees with previous reports in some European countries and India (Mossong et al. 2008, Kishore et al. 2010). One explanation for this observation is that a greater proportion of individuals acquire infection at childhood. Pregnant women that have been transfused with blood in the last five years demonstrated a significantly higher rate of $\operatorname{IgM}$ antibodies. This finding agrees with reports that linked B19 infection with blood transfusion (Parsyan \& Candotti 2007, Kishore et al. 2010) and raises an important transfusion policy question in Nigeria. Given the nature of the complications of B19 infection during pregnancy, we recommend, as a matter of transfusion policy, routine screening for B19 IgM antibodies in all blood donors, especially those donating to women.

TABLE II

Parvovirus B19 IgM antibodies by risk factors among pregnant women in Nigeria

\begin{tabular}{|c|c|c|c|c|}
\hline \multirow[b]{2}{*}{ Risk factor } & \multicolumn{2}{|c|}{ Sera analyzed } & \multicolumn{2}{|c|}{ Statistical values } \\
\hline & $\begin{array}{l}\text { Total } \\
\text { (n) }\end{array}$ & $\begin{array}{c}\text { Positive sera } \\
\text { n (\%) }\end{array}$ & $\mathrm{X}^{2}$ & $\mathrm{p}$ \\
\hline \multicolumn{5}{|l|}{ Gestational age } \\
\hline 1st trimester & 114 & $15(13.2)$ & - & - \\
\hline 2nd trimester & 135 & $18(13.3)$ & 0.01 & 0.99 \\
\hline 3rd trimester & 24 & $3(12.5)$ & - & - \\
\hline \multicolumn{5}{|c|}{ Complication history } \\
\hline Miscarriage & 54 & $9(16.7)$ & - & - \\
\hline Still birth & 33 & $6(18.2)$ & 2.96 & 0.40 \\
\hline Both & 15 & $3(20)$ & - & - \\
\hline None & 171 & $18(10.5)$ & - & - \\
\hline \multicolumn{5}{|c|}{ Number of household children } \\
\hline $0-2$ & 141 & $15(10.6)$ & - & - \\
\hline $3-4$ & 69 & $9(13)$ & 2.69 & 0.26 \\
\hline$\geq 5$ & 63 & $12(19)$ & - & - \\
\hline \multicolumn{5}{|c|}{ Blood transfusion history } \\
\hline Yes & 39 & $9(23.1)$ & 3.89 & 0.05 \\
\hline No & 234 & $27(11.5)$ & - & - \\
\hline \multicolumn{5}{|l|}{ Occupation } \\
\hline Student & 12 & $3(25)$ & - & - \\
\hline Business & 135 & $15(11.1)$ & 11.48 & 0.01 \\
\hline Civil servant & 81 & $6(7.4)$ & - & - \\
\hline Full house wife & 45 & $12(26.7)$ & - & - \\
\hline
\end{tabular}


TABLE III

Parvovirus B19 IgG antibodies by risk factors among pregnant women in Nigeria

\begin{tabular}{|c|c|c|c|c|}
\hline \multirow[b]{2}{*}{ Risk factor } & \multicolumn{2}{|c|}{ Sera analyzed } & \multicolumn{2}{|c|}{ Statistical values } \\
\hline & $\begin{array}{l}\text { Total } \\
\text { (n) }\end{array}$ & $\begin{array}{c}\text { Positive sera } \\
\text { n }(\%)\end{array}$ & $X^{2}$ & $\mathrm{p}$ \\
\hline \multicolumn{5}{|l|}{ Gestational age } \\
\hline 1st trimester & 114 & $30(26.3)$ & - & - \\
\hline 2nd trimester & 135 & $42(31.1)$ & 3.67 & 0.16 \\
\hline 3rd trimester & 24 & $3(12.5)$ & - & - \\
\hline \multicolumn{5}{|l|}{ Complication history } \\
\hline Miscarriage & 54 & $21(38.9)$ & - & - \\
\hline Still birth & 33 & $9(27.3)$ & 6.58 & 0.09 \\
\hline Both & 15 & $6(40)$ & - & - \\
\hline None & 171 & $39(22.8)$ & - & - \\
\hline \multicolumn{5}{|c|}{ Number of household children } \\
\hline $0-2$ & 141 & $27(19.1)$ & - & - \\
\hline $3-4$ & 69 & $21(30.4)$ & 12.69 & 0.0 \\
\hline$\geq 5$ & 63 & $27(42.9)$ & - & - \\
\hline \multicolumn{5}{|c|}{ Blood transfusion history } \\
\hline Yes & 39 & $12(30.8)$ & 0.25 & 0.62 \\
\hline No & 234 & $63(26.9)$ & - & - \\
\hline \multicolumn{5}{|l|}{ Occupation } \\
\hline Student & 12 & $3(25)$ & - & - \\
\hline Business & 135 & $33(24.4)$ & 4.30 & 0.23 \\
\hline Civil servant & 81 & $21(25.9)$ & - & - \\
\hline Full house wife & 45 & $18(40)$ & - & - \\
\hline
\end{tabular}

We discovered that the rate of IgM antibodies was significantly highest among full-time house wives, followed by students, businesswomen and those women that were civil servants. There is no concrete explanation for this. However, a possible explanation for this is that children are more prone to infection with this agent and that fulltime housewives are with their children all day; therefore, their environment potentiates frequent contact for transmission via aerosols. The proportion of the women that demonstrated IgM antibodies $(\mathrm{p}>0.05)$ and IgG antibodies $(\mathrm{p}<0.05)$ increased with the number of children in a household. A previous report claims that children are the main sources of transmission and outbreaks can persist for months in schools and day care centres due to the relatively large number of seronegative children that come in close contact with children within this environment (Grilli et al. 1989). Another study reported that the infection is commonly passed through respiratory tract secretions from close personal contact (Corcoran \& Doyle 2004). This justifies our finding that those with more children were more likely to be infected.

Women in their second trimester of pregnancy were found to demonstrate the highest rate of $\mathrm{IgG}$ antibodies $(31.1 \%)$ followed by those in their first $(26.3 \%)$ and third $(12.5 \%)$ trimesters. However, this did not reach statistical significance $(\mathrm{p}>0.05)$, indicating that this observation might be a product of chance. The high proportion of individuals that demonstrated IgM antibodies among the pregnant women is alarming considering the known dangers posed by this agent in pregnancy. Like other blood-transmissible viral infections, we recommend that routine screening for B19 IgM antibodies should, as a matter of policy, be made compulsory in Nigeria, especially for donors donating to women of childbearing age. We also recommend routine screening for B19 IgM antibodies for all women of childbearing age and subsequent clinical management of positive cases. Our findings have important implications for transfusion and foeto-maternal health policy in Nigeria.

\section{ACKNOWLEDGEMENTS}

To Mr Nana Jeanmaria, the Director of Nanel Medical Laboratory Jos, the management of National Blood Transfusion Service and the Department of Medical Microbiology, University of Jos, for their support and cooperation during this research.

\section{REFERENCES}

Corcoran A, Doyle S 2004. Advances in the biology, diagnosis and host-pathogen interactions of parvovirus B19. J Med Microbiol 53: $459-475$.

Cossart YE, Field AM, Cant B, Widdows D 1975. Parvovirus-like particles in human sera. Lancet 1: 72-73.

Elnifro E, Nisha AK, Almabsoot M, Daeki A, Mujber N, Muscat J 2009. Seroprevalence of parvovirus B19 among pregnant women in Tripoli, Libya. J Infect Dev Ctries 3: 218-220. 
Gratacós E, Torres PJ, Vidal J, Antolín E, Costa J, Jiménez de Anta MT, Cararach V, Alonso PL, Fortuny A 1995. The incidence of human parvovirus B19 infection during pregnancy and its impact on perinatal outcome. J Infect Dis 171: 1360-1363.

Grilli EA, Anderson MJ, Hoskins TW 1989. Concurrent outbreaks of influenza and parvovirus B19 in a boys' boarding school. Epidemiol Infect 103: 359-369.

Heegaard ED, Brown KE 2002. Human parvovirus B19. Clin Microbiol Rev 15: 485-505.

Johansson S, Buchmayer S, Harlid S, Iliadou A, Sjöholm M, Grillner L, Norman M, Sparén P, Dillner J, Cnattingius S 2008. Infection with parvovirus B19 and herpes viruses in early pregnancy and risk of second trimester miscarriage or very preterm birth. Reprod Toxicol 26: 298-302.

Kaur P, Basu S 2005. Transfusion-transmitted infections: existing and emerging pathogens. J Postgrad Med 51: 146-151.

Keikha F, Miri-Moghaddam E, Sharifi-Mood B 2006. Prevalence of parvovirus B19 infection in successful and unsuccessful pregnancy in Zahedan, southeast of Iran. J Med Sci 6: 495-497.

Kishore J, Srivastava M, Choudhary N 2010. Standardization of B19 IgG ELISA to study the seroepidemiology of parvovirus B19 in north Indian voluntary blood donors. Asian J Transfus Sci 4: 86-90.

Letaïef M, Vanham G, Boukef K, Yacoub S, Muylle L, Mertens G 1997. Higher prevalence of parvovirus B19 in Belgian as compared to Tunisian blood donors: differential implications for prevention of transfusional transmission. Transfus Sci 18: 523-530.

Markenson GR, Yancey MK 1998. Parvovirus B19 infections in pregnancy. Semin Perinatol 22: 309-317.
Morey AL, Ferguson DJ, Fleming KA 1993. Ultrastructural features of fetal erythroid precursors infected with Parvovirus B19 in vitro: evidence of cell death by apoptosis. J Pathol 169: 213-220.

Mossong J, Hens N, Friederichs V, Davidkin I, Broman M, Litwinska B, Siennicka J, Trzcinska A, Van Damme P, Beutels P, Vyse A, Shkedy Z, Aerts M, Massari M, Gabutti G 2008. Parvovirus B19 infection in five European countries: seroepidemiology, force of infection and maternal risk of infection. Epidemiol Infect 136: 1059-1068.

Obeid OE, Alzahrani AJ 2010. Analysis of chemokines and soluble adhesion molecules in cytomegalovirus-positive renal transplant recipients. J Infect Dev Ctries 4: 110-113.

Parsyan A, Candotti D 2007. Human erythrovirus B19 and blood transfusion - an update. Transfus Med 17: 263-278.

Schwarz TF, Gürtler LG, Zoulek G, Deinhardt F, Roggendorf M 1989. Seroprevalence of human parvovirus B19 infection in Sao Tome and Principe, Malawi and Mascarene Islands. Zentralbl Bakteriol 271: 231-236.

Silingardi E, Santunione AL, Rivasi F, Gasser B, Zago S, Garagnani L 2009. Unexpected intrauterine fetal death in parvovirus B19 fetal infection. Am J Forensic Med Pathol 30: 394-397.

Skjöldebrand-Sparre L, Tolfvenstam T, Papadogiannakis N, Wahren B, Broliden K, Nyman M 2000. Parvovirus B19 infection: association with third-trimester intrauterine fetal death. BJOG 107: 476-480.

Wikipedia 2010. [homepage on the internet] Jos. Wikipedia, the free encyclopedia [updated 2010 September 21; cited 2010 October 1]. Available from: http://en.wikipedia.org/wiki/Jos. 